\title{
THE WONDERS OF MOBILE PHONE TECHNOLOGY IN TEACHING AND LEARNING ENGLISH
}

\author{
Agelyia a/p Murugan \\ AIMST University, Malaysia \\ Email: agelyia@aimst.edu.my \\ George Teoh Boon Sai \\ Universiti Sains Malaysia, Malaysia \\ Email: georgeteoh@usm.my
}

APA Citation: Murugan, A., \& Sai, G. T. B. (2017). The wonders of technology in teaching and learning English. Indonesian EFL Journal, 3(1), 57-68

\begin{abstract}
Using digital tools such as Mobile phones in learning environment is beneficial as the device which is capable to present learning content and provide a wireless two-ways communication between the educator and learners. A review of researches done in Malaysia shows that studies are still focusing on the readiness of the educators and learners in using mobile learning technology in teaching and learning. This paper advocates the use of mobile phones in teaching and learning English. Theories relating to mobile learning highlight the importance of control, context, and communication elements in mobile learning. These three elements are important in knowledge building and support the positive behavioural change of the learners. Apart from that, mobile phones enable the learners to strengthen their language skills as it promotes an environment that motivates the learners to be explorative. In order to meet the students' needs, there are many types of mobile phone applications that assist learning such as discussion forum, text-based activities, audio-based learning, and interactive game-based language learning. The paper significantly highlights the importance of mobile phones and mobile phone applications which allow language learners to learn and enrich their language anytime and anywhere because the learning process can happen while on the move.
\end{abstract}

Keywords: mobile learning technology, mobile phone, English language skills

\section{INTRODUCTION}

The emergence of technology is among the most consequential thing that happened to humanity; affecting the size of the world population, life expectancy, education, living standards, the workforce, communication, health, war, and also the ecosystem (Bostrom, 2006). Apart from that, technology has also affected many things including the governance of the countries, entertainment industries, relationships, moral development, and also knowledge development of human beings. In line with Bostrom's statement, Collins and Halverson (2009) stated that the world of education is also currently going through a massive transformation due to the digital revolution to cater to the current needs of the learners in allowing them to decide on what to learn, when to learn, where to learn, and how to learn.

This rapid development has introduced a new phase of learning known as 'virtual learning' where new learning and teaching opportunities contradict with the traditional way of teaching and learning in schools.

\section{- Uniform Learning versus}

Customization. In schools, all knowledge is taught equally at the same time whereas knowledge can be customized according to the individuals' interest and difficulty levels in using technology.

- Teacher versus Knowledge Sources. Teachers are the dominant people who are seen as the expert of their field and their job is to disseminate the knowledge 
equally to the students. But with technology, knowledge can surpass teachers' expertise since diverse knowledge sources are now being offered unlimitedly through online.

\section{- Standardized Assessment versus} Specialization. Assessments in schools are limited to the subject matters that have been taught, but through technology, assessments can be specially designed based on the individuals' differences and this provides flexibility of learning according to the learners' own directions.

- Coverage versus Knowledge Explosion. Knowledge is taught as a coverage in schools where everything is being planned and set in different ways of delivery such as lectures, textbooks, and modules whereas the current technology has allowed learners to learn and find limitless knowledge independently.

Collins and Halverson (2009) believed that schools will become less important as a venue for education in the near future. They suggested that since technology is becoming central to human life, virtual learning where knowledge is being taught and shared despite the distance between the educators and the learners will become more popular. Home schooling is becoming popular in foreign countries among busy parents who travel frequently as their children are obliged to follow their parents as well. This type of education is beneficial because the bond between the students and their parents becomes closer, the students can be monitored easily and tutored privately, there is a reduction in peer pressure, and the learners gain a sense of responsibility in governing their own learning.

Technology gives more freedom in learning than didactic classroom teaching as the content learnt varies according to the individuals (Collins \& Halverson, 2009). The diversity of knowledge explosion may broaden the horizons in education world. The learners will have opportunities to choose their own educational goals and they will be exposed to complicated and different kinds of views and issues which later develop them to become more matured individuals.
There will be also less competition in the learning environment because learning in school is more competitive and pressured and the sense of failures and passes overwhelms the students' emotions and it can bring negative effects on them. The internet generally contains thousands of sources for learners to learn from, ranging from authentic materials, eBooks, podcasts, downloadable tasks, songs, movies and many more. Thus, the internet has provided more opportunities for teachers and learners to fully utilize it.

Collins and Halverson (2009 p. 8) stressed that "to be effective in this changing environment requires the builders of the new education system understand the imperatives of the technology such as customization, interaction, and control that drive the changes in education." These three imperatives are important for students' ownership of learning because the delivery of the knowledge is being guided through feedbacks and engagement of the students towards learning.

Mobile learning technology is a dynamic tool in facilitating the teaching, learning, and research efforts among the educators and the students in this 21st century (Mohamed 8 Norazah, 2013). Mohamed and Norazah (2013) stated that mobile learning can be championed by different learning theories namely behaviourist learning, constructivist learning, collaborative learning, situated learning, and informal lifelong learning. Mobile digital tools can enhance one's skills such as in the area of language, communication, motivation, and thinking skills.

A number of researches remarked that mobile learning can contribute to the rapid development of education in Malaysia (Mohamed \& Norazah, 2013; Mariam \& Balakrishnan, 2014; Maryam \& Marlia, 2012; Supyan, Mohd Radzi, Zaini, \& Pramela, 2012; Wollard, 2012). The researchers further posit that insights from the findings of the research done on the readiness of the educators in using mobile technology in teaching and learning should be implemented in a real classroom practice (Mohamed \& Norazah, 2013) in order to promote the effective use of mobile phone technology in education. 
One of the mobile learning technology devices that can be used in the classroom is mobile phones. This paper highlights the importance of mobile phones and discusses the theories relating to mobile learning and the use of mobile phone applications to enable language learners to learn and enrich their language anytime and anywhere.

\section{Mobile Technology and the importance of Mobile Phones in Education}

Mobile technology plays an important role in education. Tan and Wah (2014) define mobile learning as e-learning through mobile computational devices and is aided by a connection system called wireless local area network or Wi-Fi. Mobile Learning is seen as a new way to guide and support learners and it also complements the existing learning structure (Maccallum, 2010). Maccallum's research also shows that mobile technology affects students' extrinsic and intrinsic motivation to enhance their knowledge and competencies.

In this new learning era, mobile phones are popularly used in the developing world (Valk, Ahmed, \& Elder, 2010). Mobile phones facilitate Mobile Learning by improving access to education, promoting new learning, and providing new instructional methods (Valk, Ahmed, \& Elder, 2010). Mobile phones create opportunities for the learners to participate actively in the learning process and in their knowledge construction. Valk, Ahmed, and Elder (2010) proposed that mobile phones are capable of making the students learn independently and customize their knowledge learning while meeting specific educational goals. Apart from that, learning through mobile technology has the potential to decrease cost and increase flexibility while enhancing the efficiency and effectiveness of the educational pedagogy. Valk, Ahmed, and Elder (2010, p. 7) also stated that "the new learning through mobile technology is increasingly personal, usercentered, networked, ubiquitous and durable.......and benefits afforded by this convergence should exert a positive impact on educational outcomes".

Using mobile learning technologies in these 21st centuries' classrooms offers teachers and students a more flexible approach to learning. Prensky (2001) in Wylie's 'Mobile Learning Technologies for $21^{\text {st }}$ Century Classrooms' posits that students nowadays have changed radically. These types of students are seen as 'digital natives' who are extremely being exposed to more gadgets and technology. He also found that mobile technology has profound effects on how the students being engaged in learning when using the technological gadgets because it is what they are most used to interact with. Some of the educators see that 'Cell Phones' are distractions in the classroom. They need to be forward thinking in integrating mobile learning devices into the curriculum/ syllabus/course content as this could be a productive way in motivating and engaging the students in learning. Marwan, Madar, and Fuad (2013) found that students' previous knowledge and experience with ICT have positively influenced the students to perceive mobile phone technology as a positive introduction to learning and that they would adopt it readily.

\section{Viewing mobile learning from a Socio- Cultural perspective}

Kearney, Schuck, Burden, and Aubusson (2012) advocate viewing mobile learning as 'a potentially useful lens for researchers' to analyze the pedagogical approaches. This will help teachers to critique and reflect on their teaching activities and offers critical insights into the design of m-learning materials.

The researchers' focus was on building a framework on communication in context in evaluating mobile learning and has included three important distinctive features: Personalization, Authenticity and Collaboration.

The important elements in 'Personalization' are the learners' choice, agency and self-regulation. Personalization is an important aspect in motivating the mobile users because the users may have control on the devices and also the time and space of learning while enjoying the autonomy over the learning content. Another feature that provides the real world relevance and personal meaning to the learner is 'Authenticity'. It is suggested that authenticity in mobile learning has the 
potential to influence the learners to participate in rich, contextual tasks, and real life practices. Meanwhile, 'Collaboration' refers to the learning interactions among the learners and the pedagogical aspect involved in collaboration is through scaffolding. According to Vygotskian theory, collaboration in mobile learning is important because 'shared conversational spaces mediated by mobile devices are conducive to timely, personally tailored feedback from instructors as well as rich peer interactions.' Through collaboration, the learners can communicate with many peers and experts in their own field and also exchange information across time and place.

\section{Mobile Technology in Learning English}

Mobile learning has taken the learning of English, either in or outside the classroom hours, to a different level (Rivoltella, 2008). There are a variety of new Android applications for learning English via Smartphones and Tablet. These applications promote independent learning, realistic language practice, interactive learning, learner control, and fun in learning since the students learn using the devices or gadgets that are familiar to them.

Wagner (2005, p. 52) stated that "“"the success of mobile learning will ultimately revolve around a mosaic of rich converged experiences. These experiences will rest, in turn, on a foundation of converged network and device technologies, wireless services, rights management, content management, search management, and transactional processing power". This shows that the use of mobile learning will facilitate communication, collaboration, and creativity among learners in authentic and appropriate contexts of use. This will become more of a personalized learning.

The use of mobile learning in the English Language Classroom has a lot of benefits and guidance for learners to use and apply it in their everyday live. The full utilization of this wonderful technology will take learners to higher thinking order skills where they get to understand, develop, and treat technology as not something which they have to use but a tool which they can apply and learn from. This will further develop their technological skills towards achieving a sense of satisfaction in their learning process.

Using mobile devices in the teaching and learning scenario can be regarded as 'catching up learning quickly.' This is because the mobile language learning applications can be accessed anytime and anywhere. It is believed that mobile technology can enrich the learning process for students due to its versatility, encourage a high motivation and active participation in the classroom.

\section{Related studies on the use of Mobile Technology in Education}

\section{Title: Emerging Technology has Positive Impact in Classroom}

In the study conducted at the Bullis School (Bullis School, 2011) in the United States, a private school teacher found it difficult to keep her students engaged in the difficult mathematics curriculum. She often found that many students always leave the class with more questions than answers. After a while, she decided to transform the method of teaching by uploading her lectures in the iTunes and assigned them as homework. According to Roshan (2011), 'Instead of lecturing in class, I lecture to them when they are at home, and we work problems together in the classroom, I liken it to an English classroom where the kids go home and do the reading and they come into class and have this lively, engaging discussion.' Apparently, this method could give some space for the teacher and the students to have more time for the questions and answers in enhancing the students' understanding on a particular subject or issues.

The study, 'IT Opportunities in the Education Market' (2011) revealed that 78 percent of K-12 teachers and administrators believe that technology has positively impacted the classroom and the productivity of the students. It seems that technology provides more freedom and flexibility for the educators, but budget for the technology equipment and tools are always the issue. House, a former instructor at Belmont University posits that technology is only as good as the teachers who are using it and the use of smart phones and tablets has helped students to do research and communicate. 
She further posits that 'I don't think that your material ever gets old if you are delivering it effectively'. According to her, traditional teaching method may bring a tremendous disconnected feeling among the students and teachers need to optimize the available technological tools so that the students can be motivated in the learning process.

\section{Title: A New Face of Education; Bringing Technology into the Classroom in the Developing World}

This article found that Mobilink-

UNESCO had established a program in 2012 to increase literacy skills among girls in Pakistan. This program focuses on the girls in Pakistan who lives in villages and has limited exposure of education. For example, the girls are given mobile phones to send SMS to their teachers and receive the responses via SMS too. After that, the girls are required to write the responses in their notebook in order to practise writing skills. This program is done from the safety of their home and also during their school break. Smith and Winthrop (2012)

This program managed to unveil positive outcomes after four months because it is stated that "the percentage of girls who achieved A level on literacy examinations increased from 27 percent to 54 percent. Likewise, the percentage of girls who achieved a $C$ level on examinations decreased from 52 percent to 15 percent' (2012, p. 3). Thus, it clearly shows that modern technology can be harnessed to improve the education status of some of the world's poorest countries.

\section{Title: Mobile Technology Can Enhance Student Learning and Workforce Training.} According to Heiphetz (2011), there are variety reasons to support the adoption of mobile learning (or known as mLearning) for educating and training students. The advantages are:

1. Makes content universally accessibleanytime, anywhere.

2. Adapts to students and employee' needs.

3. Increases knowledge retention and saves time.

4. Encourages knowledge sharing and gathering.
5. Adapts to the needs of the organization

6. Creates best practices.

Heiphetz (2011) stresses that the use of mobile technology allows the learners to have free access to the contents and freedom in learning in which it can be customized to their own learning schedule. It can also keep the students updated their learning process, no matter in or out of lecture hours. Heiphetz also quoted from Kenny's paper entitled 'Using Mobile Learning to Enhance the Quality of Nursing Practice Education' to support his statement about the necessity of the usage of mobile learning in education. It is found that the nursing students can access their mobile devices for immediate references during their nursing practice. It seems that it has been the most useful features during the nursing practice because it enables them to email or query their instructors immediately. The students view the help of this mobile technology as a necessary thing nowadays to support them at the critical moments.

\section{Title: Students using their own} technological device in the classroom: Can 'BYOD' increase motivation and learning by Marc Vanwelsenaers (2012)

BYOD means Bring Your Own Device in the classroom to enhance and improve students' learning (Vanwelsenaers, 2012). This research was done to compare the students' achievement before and after the implementation of the BOD program. His research questions focused on how mobile learning technologies influenced the students' learning experience, whether or not it can improve students' learning in the classroom, and also how these devices motivate them to learn. Vanwelsenaers (2012) found that the technology created a positive learning atmosphere for most of the students. The use of mobile touch screen technology improved students' engagement in the subject matter, communication and interaction with peers as it extended the place and time of learning by not restricting learning time to the classroom.

Vanwelsenaers (2012) advised that teachers should promote cultivate a sharing attitude among the students during learning 
time because technologies may not be available to all students. He further explained that teachers need to adjust their instruction methods and lessons in their classroom teaching to promote mobile learning. Westera (2012, p. 8) concurred with Vanwelsenaers's (2012) positive findings on the usage of the mobile technology in the classroom. He stated that 'technology combined with social media for educational purposes will be important for today's students to enhance knowledge, creativity, collaboration and innovation in the classroom and to take these skills when they join the workforce.'

Vanwelsenaers (2012) suggested that further studies should concentrate on how these technologies can impact the students' learning and students from various grades. He suggested that the research should be conducted for at least a year to allow students to learn and improve sufficiently and to enable significant data collection in this area.

\section{Related studies on the use of Mobile Technology in the Malaysian Education System}

\section{Title: An Overview of Mobile Application in Learning for Student of Kolej Poly-Tech MARA (KPTM) by using Mobile Phone} Marwan, Madar and Fuad (2013) emphasis that mobile phones have the potential and ability to facilitate the learning process without a learner being tied up in a physical location of the learning process. These researchers stated that the use of mobile phones in the teaching and learning process is still at the infancy stage in Malaysia and many research done are basically on the readiness and acceptance of mobile technology in education. With the advancement of technology and the affordability of mobile phones; there is for educators not to integrate the use of mobile phones at higher learning institutions. The researchers also strongly posit that "in Malaysia, we should grab the opportunities available in the m-Learning technology to produce students who are competitive and able to master the generic skills that should be available in the students" (2013, p. 535).
Title: Teaching via Mobile Phone: A Case Study on Malaysian Teachers' Technology Acceptance and Readiness

Another study in relation to the acceptance and readiness of mobile technology by the teachers was done by a group of researchers from the School of Distance Education, Universiti Sains Malaysia in 2013, Issham, Siti, Siti, and Nizuwan. This study investigated whether the teachers in school are ready to accept technology for the pedagogical use of mobile phone technology if it was implemented in the school. Finally, it was found that although the teachers were highly motivated to accept mobile technology in the learning process, the data revealed that they were still not ready for the use of mobile technology in the classroom. The researchers explained that this may be due to some factors such as lack of confidence, lack of competence, and lack of access to the available resources.

This study mobile learning still has a long way to go before it can implemented in Malaysian schools. The researchers argued that if students were allowed to bring their own phones to school and teachers were equipped with the knowledge and skills to optimise the promising mobile phone in the teaching and learning process, mobile phones would be a wonderful tool to facilitate education.

\section{Framework of Mobile Technology Learning Resources}

In the following section, a framework and theories regarding the use of mobile technology as learning resource are presented. Sharples, Taylor and Vavoula (2007) proposed a theory of learning for the mobile age as they believe that learning can take place from a new angle that can enhance the learners' understandings of the knowledge and skills. Through mobile learning, learners can engage in an impromptu learning environment anytime and anywhere. Sharples, Taylor and Vavoula (2007) also suggested that this theory of mobile learning must be tested against a few criteria such as whether it is significantly different from current theories in the classroom, formal and informal learning, the 
impact of constructive and social process in this learning theory and also whether it can be used to analyse learning as a personal and situated activity by using the technology.

The framework as shown in Figure 1 explains how Mobile Phone Technology can be used as a learning resource where human and technology can collaborate to create and share meaning of the knowledge and skills.

The interaction process directs to the subject (learners) and the object (content knowledge and skills) where both are needed in the Control, Context and Communication factors that could influence and enhance learning in this new world of global digital communication.

Taylor, Sharples, O'Malley, Vavoula and Waycott (2006) stated that when the learners are in the control of their learning by incorporating technology, there will many benefits gained through the delivery of the knowledge. To support this, it has been said that 'if the learners can access materials as and when convenient, they can work through the materials at their own speed, revising and re-checking as they wish.' Apart from that, the learners' attitude and their social circle also can influence on how people perceive the use of technology by the learners.

Sharples, Taylor and Vavoula (2007,

p. 13) stated that "context embraces the multiple communities of actors (both people and interactive technology) who interact around shared objectives, mutual knowledge, orientations to study, styles and strategies of learning." The relationship between technology and the learners are built through communication. When the learners are communicating, they will become familiar with technology and will be explorative in terms of interacting by using emails, messengers, instant messaging, and also online chatting. On a broader scale, communicating through technology enables the learners to create rules and exclusive communities for the new ways of learning and practices (Sharples, Taylor \& Vavoula, 2007).

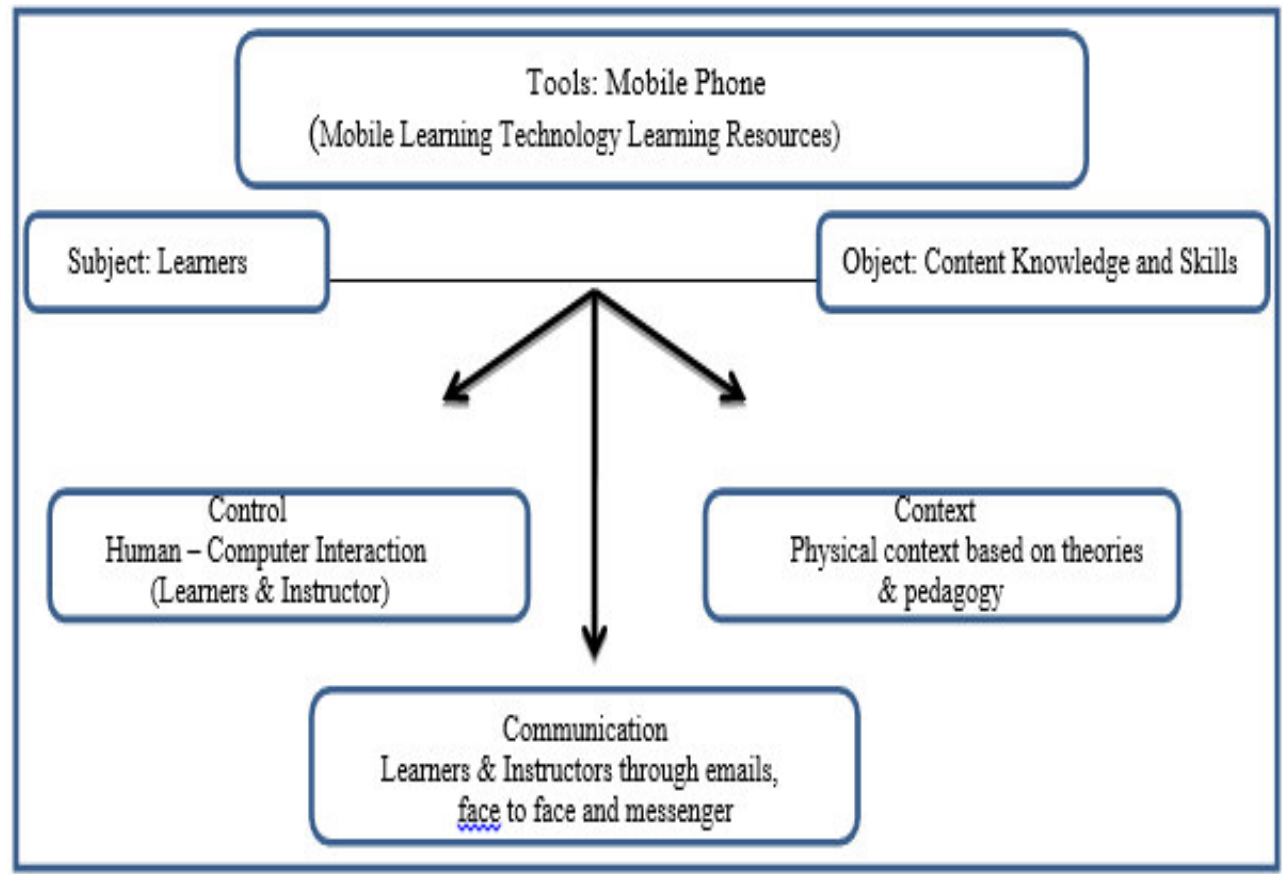

Figure 1: Framework for Analyzing Mobile Learning (Adapted from Maccallum, 2010)

Below are some of theories involved in using Mobile Phone as a learning resource by integrating the significant factors such as Control, Context and Communication. These three factors are important in the unique interaction between human and technology where knowledge is embodied through valuable experience. Without these theories, 
learning across the context cannot be achieved because learning has to be conceptualised in order to construct knowledge within the constraints of the education curriculum. As what supported by Sharples, Taylor and Vavoula (2007), learning needs to be conceptualised in terms of interactions between individuals, human or non-human, which take place in order to achieve evolving tastes of knowing as they are shaped by mutually and continuously negotiated goals.

\section{Theory of Learning Using Mobile Technology Social Constructivism}

This theory is largely influenced by Vygotsky's Cognitive theory (Sharples, Taylor, \& Vavoula, 2011) which stresses that mobile learning through mobile devices expose the learners to simulations and visualizations.

This theory is important in building the knowledge of the learners where learners will be an active player in the learning experience and also connect with their previous assimilated knowledge to construct a new knowledge (Tan \& Wah, 2014). Tan \& Wah (2014) added that constructivism creates capable learners who reproduce a series of facts and it does not dismiss the active role of the teacher or the value of expert knowledge as the knowledge is constructed through interaction with the environment after a series of mental structures.

This theory also leads us to 'Computer Supported Collaborative Learning (CSCL)' where knowledge is constructed by the learners through the assistance of technology.

\section{Computer Supported Collaborative Learning (CSCL)}

This pedagogical approach consists of various disciplines; including Sociology, Educational Psychology, Cognitive development, and Instructional Technology. This Collaborative Learning is supported by using computers for the primary means of communication and is believed to increase the quantity and quality of the learning capacity. Berge (2006, p. 49) stressed that "collaboration theory proposes that technology in support of CSCL should provide new types of media that foster the building of collaborative knowing; facilitate the comparison of knowledge built by different types and sizes of groups; and help collaborative groups with the act of negotiating the knowledge they are building." This instructional technology is an integral part of society today and fulfills the needs of the digital generations.

\section{Experiential Learning Theory}

Experiential learning theory is closely related to content-based and theme-based instruction in teaching and learning. Morries, Keeton and Pamela in Brown (2001) stated that learners are directly in touch with the realities being studied and the techniques tend to be learner-centred by nature. Through experience, learners are expected to discover the principles of the language and connect to the content of the knowledge. This model is initiated by David Kolb, based on learning through reflections.

Kolb's (1984) learning theory sets out four distinct learning styles (or preferences), which are based on a four-stage learning cycle. Kolb's model offers both a way to understand individual learning styles, and also an explanation of a cycle of experiential learning that applies to all learners. In this stage of the learning cycle, people understand ideas and situations from different points of view. In a learning situation, the learners would rely on patience, objectivity, and careful judgement but would not necessarily take any action. The learner would rely on their own thoughts and feelings in forming opinions. Experiential activities are among the most powerful teaching and learning tools available. Experiential learning requires self-initiative, an "intention to learn" and an "active phase of learning." This process of learning can result in "changes in judgment, feeling or skills" for the individual and can provide direction for the "making of judgments as a guide to choice and action." According to Kolb, Boyatzis and Mainemelis (1999), most educators understand the important role experience 
plays in the learning process. The role of emotion and feelings in learning from experience has been recognised as an important part of experiential learning. While those factors may improve the likelihood of experiential learning occurring, it can occur without them. Rather, what is vital in experiential learning is that the individual is encouraged to directly involve themselves in the experience, and then to reflect on their experiences using analytic skills, in order to gain a better understanding of the new knowledge and retain the information for a longer time. Below is the chart of experiential learning model.

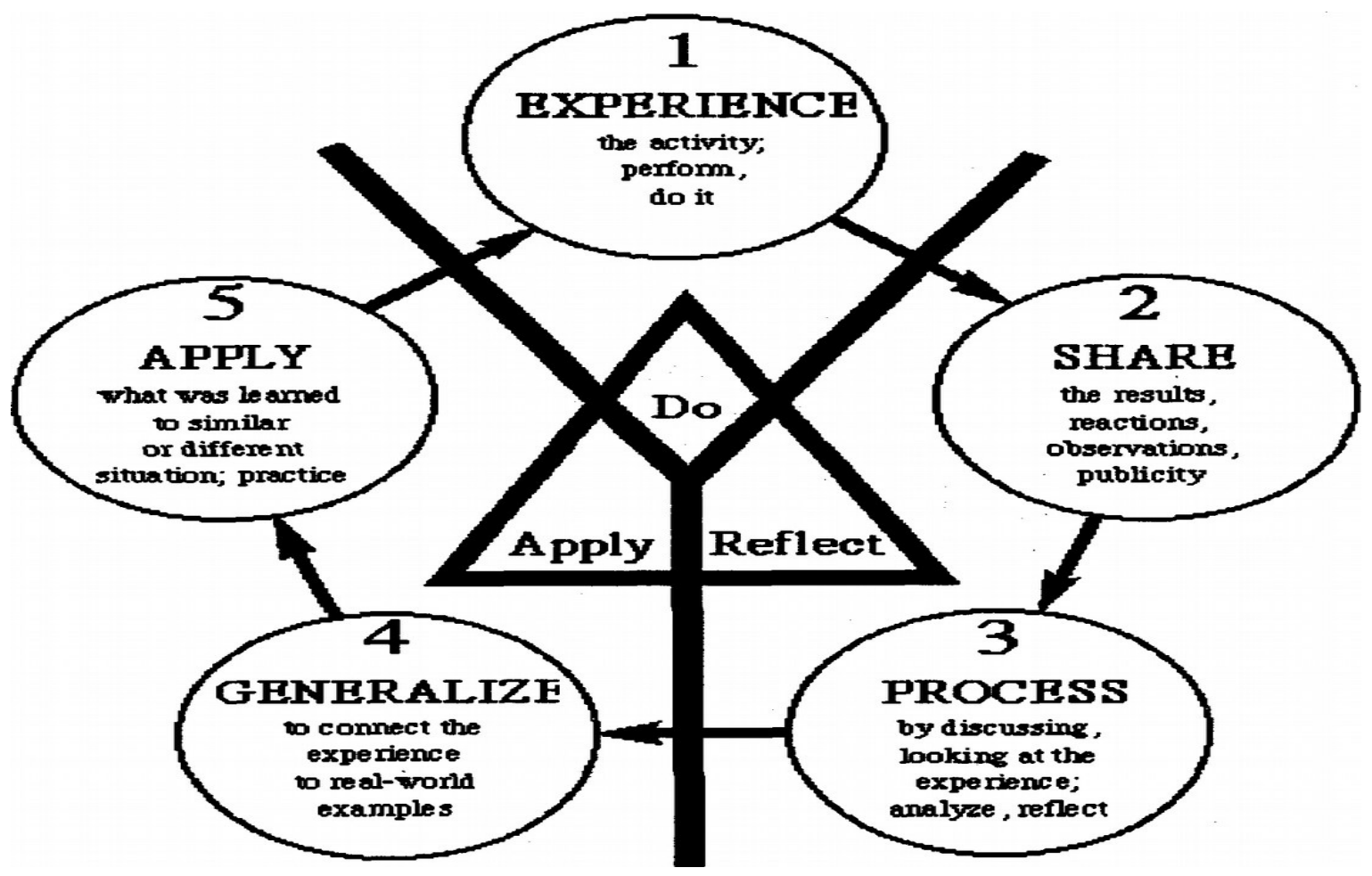

Figure 2. The Experiential Learning Cycle Facilitator Guide

\section{Communicative Language Teaching}

According to Freeman (2000), communicative language teaching was developed through the Communicative Approach (Widdowson, 1990). Its main aim is to introduce the interdependence of language and communication, more than mastering the linguistic structures of the language learning. The teacher teaches the language by using it in a real context so that the students can actively engaged in communicating and negotiating meaning without fear. In contrast, language teachers are no longer viewed as the authority of the knowledge who plays a dominant role. Rather, they share different roles such as communication facilitator, independent participant, needs analyst, counsellor, and group process manager
(Richards \& Rodgers, 2001, p. 167) to create more fascinating experiences for the learners. Besides, Richards and Rodgers (2001) describe other significant characteristics of this approach including its efforts to make tasks and language relevant to a target group of learners through an analysis of genuine, realistic situations, its emphasis on the use of authentic, from-life materials, and its attempt to create a secure, nonthreatening atmosphere. All these attempts also follow the major principles of the communicative view of language teaching and learning; helping learners learn a language through authentic and meaningful communication, which involves a process of creative construction, to achieve fluency. In this vein, in terms of classroom activity, it includes 
group work, task-work, information-gap activities, and projects.

\section{Co-operative $\&$ Collaborative Learning}

Co-operative and Collaborative

Learning approach focuses on learnercentred characteristics where it omits the competitive characteristics in the learning scenario. "Research has shown an advantage for cooperative learning (as opposed to individual learning) on such factors as *

\section{Sociocultural Theory}

Vygotsky (1978) in Taylor, et al. (2006)

stated that this theory is important in the learning process which is mediated by tools. He further explains that the tools include both physical artefacts and semiotic constructs including language and society....the focus is on the activity itself, including the processes by which social, cultural and historical factors shape human functioning. Apart from that, Vygotsky (1978) in Taylor, et al. (2006) proposed Zone of Proximal Development (ZPD) as a guideline to understand the learners and also the external opportunities given by the teachers and peers to the learners. ZPD is one of the ways to assess learners' knowledge and skills and simultaneously increase the learners' repertoire of skills and understanding effectively.

\section{Bloom's Taxonomy of Learning Domains}

For the physical context of Mobile

Phone Technology as a learning resource, the three domains; Cognitive, Affective and Psychomotor in Bloom's taxonomy are important to promote higher order thinking skills in education. The contexts available in the mobile phone learning should cover all these three domains as it involves knowledge, attitude and skills of the learners. Cognitive domain focuses on the development of intellectual skills which has three levels; Factual, Conceptual, and Procedural. On the other hand, affective domain focuses on the manner of how we deal things emotionally, appreciation, enthusiasm, motivations, and attitudes whereas psychomotor domain includes physical movement, coordination, and the use of motor skill area.

\section{Motivation and Language Learning}

The first theory of motivation was proposed by Gardner and Lambert in 1972 in which Nitta (2006) asserted that motivation and attitude is related to an individual to learn a second language. From the behaviorists' perspective, Biehler and Snowman (1993) stated that motivation relies on Skinner's learning theories which emphasized on the giving of extrinsic reward, and thus explained why students prefer certain subjects to the others. Chen (2008) also pointed out motivation is important to succeed in the second language learning. $\mathrm{Hsu}$ and Chan (2005) as reported in Chen (2008) stated that an individual who has higher motivation will achieve better in second language performance than individual who has low motivation.

Thus, it is interesting to find out if the learners' motivation to succeed in the second language is significant to his or her achievement. Instrumental motivation involves learning the second language to succeed in a job or to excel in academic. Thus, one can assume that an individual is instrumentally motivated to learn a language if this helps him or her to perform tasks efficiently in academics or find a job in the future. Norris-Holt (2001) also supported this view when she claimed that learning a language with instrumental motivation is more practical when one is trying to fulfill the graduating requirements, job applications, education, and high salary.

Unlike instrumental motivation, integrative motivation is defined as "to identify with another ethnolinguistic group' (Ellis, 1994, p. 173). Thus, one can assume that an individual is integrative motivated to learn a language if this gives him or her opportunity to live with the people, understand the culture, and interact with the second language speakers. This is because the learners also value the foreign group and intend to engage with the communities' lives and culture (Norris-Holt, 2001)."

Furthermore, Cooper and Fishman (1977) as cited in Shimizu (2002) also included a third type of motivation called "developmental" in addition to Gardner and Lambert's instrumental and integrative 
construct. Shimizu (2002) later explained that developmental motivation is much related to personal satisfaction such as watching films and reading books. Thus, identifying learners' personal motivation to learn English is significant in order to find out its relationship with English language achievement.

\section{Attitude and Language Learning}

According to Gardner (1990) as cited in Nitta (2006, p. 10), "attitude refers to the 'et al. (2007) reported that Wenden (1999) believed that attitude is cognitive since it explains the perceptions and beliefs about certain object. She further argued that attitude is also affective since it induces a feeling of preference, agreement or approval towards certain issues, and it is also behaviourist since it composes actions towards the object.

Sunnarborg (2001) also supported this view and believed that cognitive, affective, and behaviorists are interrelated. Based on this concept, one can assume that learner's perception, feelings and preference and actions are important in learning a second language. Moreover, the study on attitude is essential for second language learning because attitude together with motivation are connected with acquiring a second language (Bidin et al., 2009; AlTamimi \& Shuaib, 2009).

\section{CONCLUSION}

This paper highlights the wonders of using mobile phones to teach English. It is argued that mobile learning is a unique kind of learning which allows learning that can be customised to the learner's need. Mobile learning has emerged to be the new learning technique which can cater to the younger generation as they are learners who prefer to interact and engage themselves as they roam around in their respective environments, picking up and using devices as they go.

To prevent educators from viewing mobile learning as a distraction in teaching, teachers need to be made aware of the benefits of using this mobile technology. Educators really need to understand the characteristics, possibilities and peculiarities of mobile learning so that they can successfully conduct mobile learning. Knowing the vital elements of mobile learning will make the teachers appreciate the use of mobile phones in aiding their teaching and more importantly in their students' development, satisfaction, and motivation to enhance their knowledge and skills in learning English.

Viewed from the perspective of Vygotsky's Sociocultural theory, mobile learning is a wonderful opportunity that can support the learners through a lifetime of learning, provide them with tools to capture and organise their everyday experiences, create and share images of the world, and probe and explore their surroundings.

\section{REFERENCES}

Al-Tamimi, A. \& Shuaib, M. (2009). Motivation and attitudes towards learning English: A study of petroleum engineering undergraduates at Hadhramout University of sciences and technology. Journal of Language Studies, 9(2). Retrieved October 1, 2009, from http://pkukmweb.ukm.my/ ppbl/Gema/pp \%2029_55.pdf

Berge, O. (2006). Reuse of Digital Learning Resources in Collaborative Learning Environments. Unpublished PHD Thesis, University of Oslo.

Biehler, R.F. \& Snowman, J. (1993). Psychology applied to teaching (7th ed.). Boston: Houghton Mifflin Company.

Bostrom, N. (2006). Technological Revolutions: Ethics and Policy in the Dark. Nanoscale: Issues and Perspectives for the Nano Century, Eds. Nigel M. de S. Cameron and M. Ellen Mitchell (John Wiley, 2007).

Brown, H. D. (2001). Teaching by Principles: An Interactive Approach to Language Pedagogy, (2nd ed.). New York: Pearson Education.

Chen, W. D. (2008).A Study of ROCMA Freshmen Cadets' Motivation on English Learning. An Interdisciplinary Journal 54. Retrieved October 1, 2009 from http://www2.cma.edu.tw/ u_edu/introduction/journal/54files/ $\%$ E7\%A4\%BE\%E6\%9C $\% 83 \% \mathrm{E} 7 \% \mathrm{~A} 7 \% 91 \% \mathrm{E} 5 \mathrm{AD}$ \%B8\%E9\%A1\%9E/54-S09.pdf

Collins, A. \& Halverson, R. (2009). Rethinking Education in the Age of Technology: The Digital Revolution and the Schools. New York: Teachers College Press. Retrieved on 24th October 2014.

Ellis, R. (1994). The Study of Second Language Acquisition. Oxford: Oxford University Press.

Heiphetz, A. (2011). How Mobile Technology Can Enhance Student Learning and Workforce Training. McGraw-Hill, Research Foundation. 
Retrieved on 15th November 2013 at http://www.mcgraw-hillresearchfoundation.org

Issham, I, Siti, F. B., Siti, N. A., \& Nizuwan, A. (2013). Teaching via Mobile Phone: A Case Study on Malaysian Teachers' Technology Acceptance and Readiness. School of Distance Learning, Universiti Sains Malaysia. Retrieved on January 8th 2014.

Kearney, M, Schuck. S, Burden. K \& Aubusson. P (2012). Viewing Mobile Learning from a Pedagogical Perspective. Center for Research in Learning and Change, University of Technology, Sydney (UTS), Australia, The Center for Educational Studies, Faculty of Education, The University of Hull, Hull UK. Retrieved on $18^{\text {th }}$ February, 2015 at Research in Learning Technology, Online ISSN: 2156-7077.

Kolb, D., Boyatzis, R. C. \& Mainemelis, C. (1999). Experiential Learning Theory: Previous Research and New Directions. Care Western Reserve University.

Maccallum, K (2010). Student Characteristics and Variables that Determine Mobile Learning Adoption: An Initial Study. Retrieved on 24th October 2014.

Mariam, M. \& Balakrishnan, M. (2014). Mobile Assisted Language Learning in Malaysia: Where Are We Now? Center for Instructional Technology \& Multimedia, Universiti Sains Malaysia, Malaysia. Retrieved on $15^{\text {th }}$ September 2015 at http://worldconferences.net/ejournals/glit/wpcontent/uploads/sites/6/2014/06/GL-017Mariam-Mohamad-2.pdf

Mariam, M. \& Wollard, J. (2012). Mobile Learning via Mobile Phones: Complementing the Existing Practices in Malaysian Secondary Schools. University of Southampton (UK): International Conference of the Future of Education.

Mariam, T. \& Marlia, P. (2012). Mobile learning to support teaching English as a second language. Journal of Education and Practice, 3(7), 56-62. Retrieved on $16^{\text {th }}$ October 2014 at https://papers.ssrn.com/sol3/papers.cfm? abstract_id=2279326

Marwan, M. E., Madar, A. R. \& Fuad, N. (2013). An overview of mobile application in learning for student of Kolej Poly-Tech MARA (KPTM) by using mobile phone. Journal of Asian Scientific Research, 3(6), 527-537.

Mohamed, A. E. \& Norazah, M. N. (2013). Mobile Learning: Malaysian Initiatives $\mathcal{E}$ Research Findings. Center for Academic Advancement, Universiti Kebangsaan Malaysia \& Department of Higher Education, Ministry of Higher Education.

Nitta, T. (2006). Affective, Cognitive and Social factors affecting Japanese Learners of English in Cape Town. Retrieved October 1, 2009, from University of The Western Cape, Linguistics Department Website: http://etd.uwc.ac.za/usrfiles/modules/etd/docs /etd_gen8Srv25Nme4_4868_1210749958.pdf
Norris-Holt, J. (2001). Motivation as a contributing factor in second language acquisition. The Internet TESL Journal, VII(6). Retrieved October 1, 2009, http://iteslj.org/Articles/NorrisMotivation.html

Richards, J. C. \& Rodgers, T. S. (2001). Approaches and Methods in Language Teaching. UK: Cambridge University Press.

Sharples, M, Taylor. J \& Vavoula. G (2007). A Theory of Learning for the Mobile Age. London: Sage Publication.

Simcock, A., Shi, J., Ives, Mphande, C. \& Bronson, P. (2007). Towards Staff Awareness of Communication Education in Engineering. In Proceedings of the 2007 AaeE Conference, Melbourne (pp. 1-8). Retrieved October 1, 2009 from http://www.aaee.com.au/ conferences/papers/2007/paper_12.pdf

Smith, S. M \& Winthrop, R. (January 2012). A New Face of Education: Bringing Technology into the Classroom in the Developing World. Brooke Shearer Working Paper Series, Number 1 of 2. BROOKINGS Institution. Retrieved on 15th November 2013 at http://www.brookings.edu/research/papers/2 012/01/education-technology-winthrop

Sunnarborg, P. (2001). Exploring attitude and attitude change in second language learners. Retrieved October 1 from http://www.hamline.edu/ personal/psunnarborg/attchange.htm

Supyan, H. Mohd, R. Zaini, A. \& Pramela, K. (2012). Mobile learning readiness among Malaysian students at higher learning institutes. Asian Social Science, 8(12). Retrieved on $24^{\text {th }}$ October 2014 at http://www.ccsenet.org/journal/i ndex.php/ass/article/view/20987

Tan, C. K, Ng. S. I, Lee. K. W (2014). Readiness for Mobile Learning at a Public University In East Malaysia. Mobile Learning: Malaysian Initiatives $\mathcal{E}$ Research Findings. Center for Academic Advancement, Universiti Kebangsaan Malaysia \& Department of Higher Education, Ministry of Higher Education.

Valk, J. H, Ahmed. T. R. \& Elder, L. (2010). Using Mobile Phones to Improve Educational Outcomes: An Analysis of Evidence from Asia. The International Review of Research in Open and Distance Learning. Retrieved on 24th October 2014.

Vanwelsenaers, M (2012). Students using Their Own Technology Device in the Classroom: Can 'BYOD' Increase Motivation and Learning. Northern Michigan University. USA.

Wagner, E. D. (2005). Enabling Mobile Learning. EDUCASE Review, 40(3), 40-53.

Wylie, J. (2013). Mobile Learning Technologies for 21st Century Classrooms. Scholastic. Retrieved on 2nd November 2013 at http://www.scholastic.com 